\title{
Mitigation strategies for reducing air pollution
}

\section{Daniele Sofia $^{1,2} \cdot$ Filomena Gioiella $^{1} \cdot$ Nicoletta Lotrecchiano ${ }^{1,2} \cdot$ Aristide Giuliano $^{1,3}$}

Received: 6 December 2019 / Accepted: 27 March 2020 / Published online: 11 April 2020

(C) Springer-Verlag GmbH Germany, part of Springer Nature 2020

\begin{abstract}
Today, it is increasingly recognized that air pollution hurts human health. Consequently, efficient mitigation strategies need to be implemented for substantial environmental and health co-benefits. A valid approach to reducing the air pollution effects on the environment and human health is proposed. Specific guidelines have been elucidated by differentiating them on the base of the final stakeholders (citizens, enterprises, and public authorities), of the emission sources (transport, household energy, industry, and energy generation sector, agriculture, and shipping area), and of the field of implementation (urban and extra-urban context). This paper can provide useful information for governments for the implementation of a strategic plan focused on emphasizing multi-pollutant emission reductions and overall air pollution-related risk.
\end{abstract}

Keywords Air pollution · Mitigation strategies $\cdot$ Human health $\cdot$ Environmental impact $\cdot$ Air quality $\cdot$ Guidelines

\section{Introduction}

Today, air pollution is the main responsible for environmental quality worsening in many cities all over the world, with adverse outcomes on people's health (Vlachokostas et al. 2011). According to the last World Health Organization (WHO), more than $80 \%$ of people living in the urban context are subjected to air quality levels above the emission limits regarding air pollution. The primary atmospheric pollutants are carbon monoxide (CO), particulate matter (PM), nitrogen oxides $\left(\mathrm{NO}_{x}\right)$, volatile organic compounds $\left(\mathrm{VOC}_{s}\right)$, polycyclic aromatic hydrocarbons $\left(\mathrm{PAH}_{s}\right)$, ozone $\left(\mathrm{O}_{3}\right)$, and sulfur dioxide $\left(\mathrm{SO}_{2}\right)$. The increase in emission amounts of these pollutants is due to the rapid industrialization and urbanization of developing countries ( $\mathrm{Fu}$ and $\mathrm{Chen} 2017$ ).

The worsening of air quality in urban environments has considerable interest in the scientific community and public

Editorial Responsibility: Philippe Garrigues

Aristide Giuliano

aristide.giuliano@enea.it

1 Sense Square srl, Piazza Vittorio Emanuele 11, 84084 Fisciano, SA, Italy

2 University of Salerno, Via Giovanni Paolo II 132, 84084 Fisciano, SA, Italy

3 ENEA, Italian National Agency for New Technologies, Energy and Sustainable Economic Development, S.S. 106 Ionica, Rotondella, MT, Italy opinion due to the strong relationship between air pollution exposure and increased harmful short- and long-term effects on human health (Masiol et al. 2014). Recently, significant epidemiological studies in the literature have found that air pollution contributes to increased morbidity (especially at respiratory and cardiovascular levels), premature mortality, and finally, cancer (Brancato et al. 2018). Figure 1 summarizes the different area of diseases: neuronal (Dales et al. 2009) (Power et al. 2015) (Power et al. 2016) (Levy 2015) (Block and Calderon-Garciduenas 2009), respiratory (Brugha and Grigg 2014) (Guan et al. 2016) (Kurmi et al. 2010) (Goss et al. 2004) (Fajersztajn et al. 2013), cardiovascular (Zanobetti and Schwartz 2005) (Anderson et al. 2012) (Maheswaran 2016) (Yang et al. 2017), and oncology area (Raaschou-Nielsen et al. 2013) (Crouse et al. 2010). Each disease is affected by own pollutant exposures (PM, $\mathrm{NO}_{2}$, $\mathrm{SO}_{2}, \mathrm{CO}_{2}, \mathrm{O}_{3}$ ) with the corresponding level of risk. Human exposure to air pollutions is strongly affected by the lifestyle and by the prevailing life environment (Buonanno et al. 2014). In their work, Buonanno et al. (2012) demonstrated that essential contributions to children exposure are due to the time spent at home for cooking/eating as well as for the time spent in traffic jams moving to or from school (Buonanno et al. 2012). In addition to human health risks associated with gases and particles inhalation, urban air pollution also causes damages at an environmental level, for example, by increasing the corrosion and deterioration of materials and damaging historical monuments and buildings (Vlachokostas et al. 2011). The effects of air pollution have been studied on many assets of the 


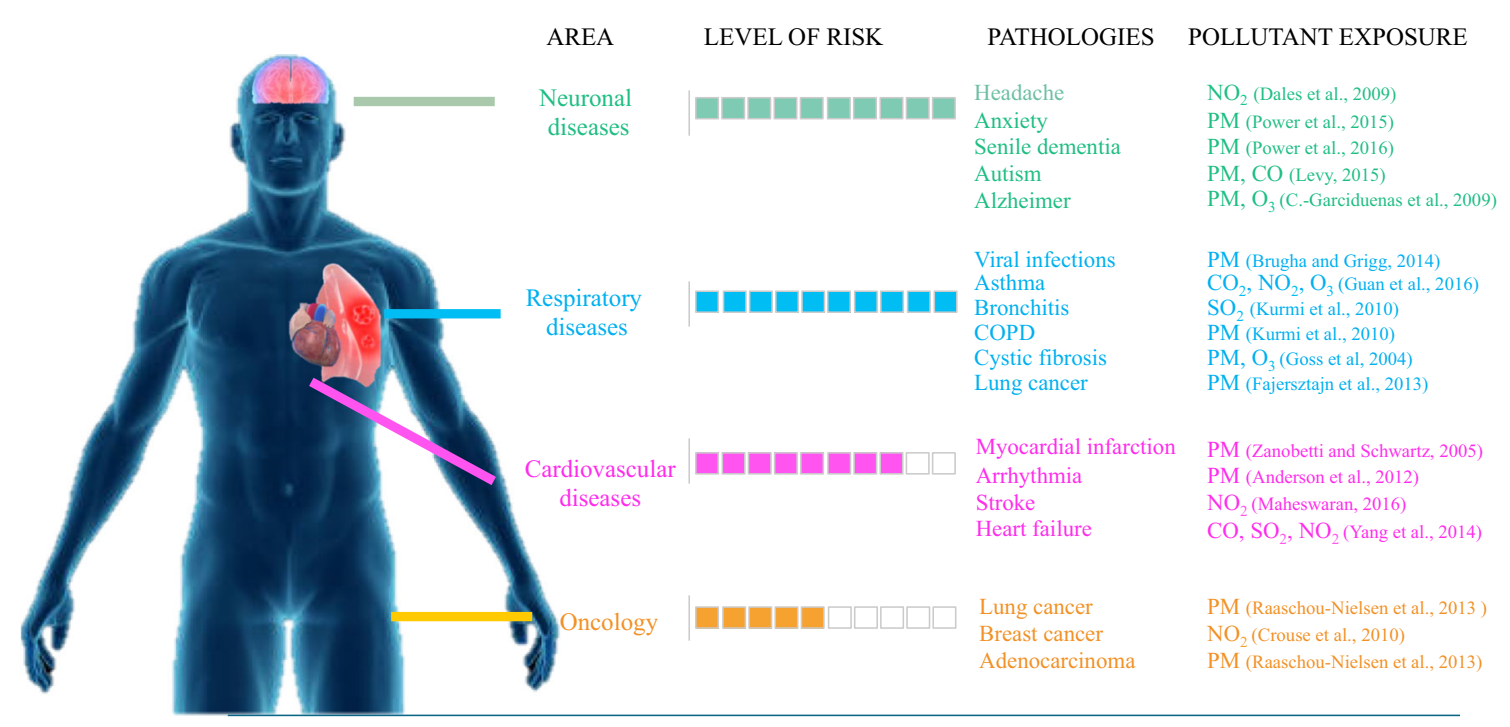

Fig. 1 Different areas of diseases in the human body

Italian artistic heritage Depending on where they are located; it was possible to verify the effects of the typical pollutants of the context itself. Sulfur dioxide reflecting the severe air pollution of this very large city can be dangerous for stone monuments as the marble Arch of Titus in Rome (Metallo et al. 1995); the particulate matter and the heavy metals as $\mathrm{Pb}$ and $\mathrm{Zn}$ can damage monuments like the Vittoriano Monument in Rome that is exposed to intense road traffic (Barca et al. 2014). The exposure to air pollution can influence also the stability of public utility buildings such as bridges as occurred in Genoa during 2018 when, due to the aggressive environmental condition that corroded the strands, the Polcevera Bridge collapsed causing 43 deaths and more than 5000 evacuated people (Invernizzi et al. 2019).

To tackle these problems, efficient long-term air pollution mitigation strategies need to be identified and implemented (Rodriguez de San Miguel 2019). For this reason, the role of the management to improve the current situation becomes critical (Werner et al. 2015). It is, therefore, crucial to define a strategic plan with some actions in compliance with the relevant directives in the field of air quality (Vlachokostas et al. 2011). These actions strongly depend on local policy and economy, on available technologies, and on public opinion (Harlan and Ruddell 2011).

\section{The aim of this work}

This paper aims to contribute to the existing knowledge on environmental pollution literature by investigating how people, companies, and committees can contribute to reducing pollution effects by engaging in pro-environmental behaviors. We firmly believe that if these proposed behavioral recommendations are pursued, positive environmental impacts and health co-benefits are very likely to occur. Among the policies that we intend to propose, the promotion of active transport and sharing mobility, the reduction of energy use in the household environment, the urban planning, the provision of benefits in favor of bio-fueled (Sofia et al. 2013), and the use of electric vehicles are included.

\section{Recommendations for citizens}

To mitigate the air pollution problem, many efforts have to be taken with the aim to decrease the pollutants emissions coming from people. Each citizen may contribute to the mitigation of air pollution through behavioral changes in their lifestyle as the reduction of energy consumption in transportation, households, and supply.

\section{Public and active transport}

Transportation is the central investigated sector for public health benefits obtained after air pollution reduction (Sarigiannis et al. 2017) (Lindsay et al. 2011). It is well known that vehicular transport produces about $70 \%$ of environmental pollution since exhaust fumes from motors are a source of several pollutants $\left(\mathrm{CO}, \mathrm{NO}_{2}, \mathrm{VOC}\right.$, and $\left.\mathrm{PM}\right)$ (Xia et al. 2015). Consequently, programs aiming at changing travel behaviors are essential (Guersola et al. 2017). Each citizen should use public transports (bus, tram, subway, train) as much as possible and possibly travel actively (walking and cycling). The shift to active transport by reducing the use of owned cars entails significant benefits for human health and environment (Rabl and de Nazelle 2012) (Maizlish et al. 2013) (Xia et al. 2015). Recently, several studies have shown that the increase in physical activity reduces the incidence of several diseases, especially at cardiovascular level (coronary heart disease, stroke), hypertension, and diabetes (Mueller et al. 2015) (Scheepers et al. 2014). Furthermore, in this 
way, significant reductions of colon and breast cancer and the improvement of mental health can be achieved (Rabl and de Nazelle 2012). Of course, benefits from physical activity are obtained by minimizing exposure to atmospheric pollution; therefore, the outdoor activity has to be carried out in the environment with healthy air (Rabl and de Nazelle 2012). Furthermore, commuters should be encouraged to use lowcost public bicycle sharing systems to combine benefits concerning health and air pollution reduction (Rojas-Rueda et al. 2011).

\section{Household sector}

Nowadays, household air pollution is attributed to the residential use of the solid fuels from cooking activities (Stabile et al. 2014) and space heating systems (Stabile et al. 2018), leading a significant hazard for the health of exposed populations (Gao et al. 2018). Accordingly, actions to reduce energy use by households and buildings are essential because of their great contribution to gas emissions (Datta et al. 2017). One of the appropriate strategies is the improvement of combustion efficiency of solid household fuels (Venkataraman et al. 2010). Generally, traditional fuels have low combustion efficiency producing accordingly large amounts of products due to incomplete combustion, with consequences for both environment and human health. In their work, Marchetti et al. (2019) demonstrated how the particles deriving from the combustion different fuels (pellet, wood, charcoal) could activate toxicological pathways, finally producing cytotoxic effects on human health (Marchetti et al. 2019). The fuel toxicity is dependent on the chemical composition of the particulate matter characterizing the quality of the combustion and fuel. The energy generated from renewable sources (biomass) should lead health benefits for citizen because of a cleaner environment with low emission production (Harlan and Ruddell 2011) with respect to the traditional fossil fuel used.

Nevertheless, more stringent regulations are required to guarantee high-quality biomass fuels and safer combustion technologies (Marchetti et al. 2019). On their side, each citizen has to adopt some behavior actions to reduce energy consumption and emissions deriving from home heating. Another essential structural adaptation is the introduction of new technologies to reduce energy use in new buildings (Ruparathna et al. 2017). Porritt et al. (2012) showed how limited changes in building are able to eliminate overheating during heat wave periods and reduce space energy use for internal climatization, such as external wall insulation, solar reflective coatings (external shutters), and painting of the outer walls in lighter colors (Porritt et al. 2011) (Porritt et al. 2012). Furthermore, green roof technologies can help to reduce local outdoor temperatures and improve the appropriate cooling inside buildings (Harlan and Ruddell 2011).

\section{Aeration}

Despite efforts to reduce particle emissions deriving from outdoor activities, most of air pollution is related to indoor microenvironment (Buonanno et al. 2017). The air quality inside buildings is affected by the air circulation, the construction materials, the use of cleaning products, and the habits of occupants (smoking). A vast range of pollutants can concentrate in indoor environments produced by individual activities in addition to outdoor concentrations (Settimo 2015). As a consequence, air exchange with particle filters, ventilating (Debnath et al. 2017), and air-conditioning systems are a distinct way of reducing air pollution in indoor spaces, like homes or shared communities (offices, schools, hospitals, sport facilities, restaurants, cinemas, and public transport) (Kwong et al. 2019). Among public buildings, school is one of the worrisome indoor environments since children represent a susceptible population to air pollution due to their age (Mainka et al. 2015).

\section{Healthy diet}

Beyond mitigation strategies to reduce air pollution, each citizen can adopt some eating habits that can influence own health status (Biesbroek et al. 2014). It was well demonstrated that the increased intake of antioxidants in foods could hinder and reduce the adverse effects of atmospheric pollution (Kelly et al. 2003). Precisely, the antioxidants are substances able to neutralize free radicals generated by some air pollutants (ozone and nitrogen dioxide). In this way, injury to respiratory tract like asthma can be avoided after their oxidant exposure (Romieu et al. 2002). Therefore, it is necessary to reduce the consumption of food deriving from animal source by promoting a healthy diet with higher consumption of fruit and vegetables.

\section{Recommendations to small, medium, and large enterprises}

Globally, one of the main contributors to emissions of atmospheric pollutants and a significant user of energy is the industrial sector (Conti et al. 2015). The pollutants deriving from industrial activities are transported into the urbanized areas. Consequently, the development of strategies to reduce air pollution is crucial. In this section, possible measures relating to industrial, agriculture, and shipping sector are introduced such as energy reduction (Pask et al. 2017), advanced technologies and process performance promotion (ContrerasZarazúa et al. 2018), improvement of the efficiency of livestock farming and manure management, and electrification of the port docks. 


\section{Industrial sector}

Even today, the primary source of energy are fossil fuels, responsible for the production of some pollutants notably particulate matter (PM) (Salehi et al. 2015), nitrogen oxides $\left(\mathrm{NO}_{x}\right)$, and sulfur oxides $\left(\mathrm{SO}_{x}\right)$ (Chao 2008). The reduction of power generation from fossil fuel sources (coal, oil, gas) imply health benefits by reducing local air pollutants, especially micronic and submicronic particles (Karka et al. 2017). Recently, several initiatives to replace fossil fuels with alternative renewable fuels have been taken into consideration (Ribeiro et al. 2015). Among the various technologies for energy production from renewable sources, the biomass combustion can represent a valid alternative technology of fossil fuels (Sripada et al. 2017) (Giuliano et al. 2018a). Shrestha and Shakya (2012) showed that the implementation of the cost minimization energy system MARKAL, based on the market allocation framework, reduces the local pollutant emissions, improving the efficiency of the national overall energy consumption. This strategy includes energy supply, conversion and process technology, end-use service demand, and environmental emissions promoting the use of renewable energy resources (Shrestha and Shakya 2012). In this way, cities will have benefits if they will move toward low carbon technologies (Ren et al. 2012).

Among the various industrial sectors, one of the primary sources of the main pollutants (VOCs, toxins, PAH) is the chemical industry (Lee and Cho 2003). As a consequence, proper air pollution control techniques have to be applied to reduce the negative environmental impact (Contreras-Zarazúa et al. 2018). Another mitigation strategy to reduce air pollution from the industrial sector is the implementation of advanced technologies in the industrial process (Babar and Shareefdeen 2014). For example, clean coal technologies (CCT) can treat and use coal in an efficient way without a substantial environmental impact (Giuliano et al. 2018b). Besides, it was demonstrated that retrofitted technologies such as catalytic converters and desulfurization reduce only local air pollution.

On the other hand, the benefits of integrated environmental strategies are higher than the ones given by air quality management plans and measures for GHG reduction. This result is highlighted in the study of Chae and Park, who demonstrated that using compressed natural gas and an efficient heating and cooling systems, both local and global air pollution reduction can be achieved (Chae and Park 2011). Furthermore, the best available techniques (BAT) are promoted to reduce the environmental impacts deriving from industrial activities since they operate minimizing costs (Ibáñez-Forés et al. 2013). This technology has to be "available" that means usable to the operator and economically and technically feasible. Additionally, it has to be "best" that means provide a high level of environmental protection as a whole (Liu and Wen 2012). As a consequence, plant owners of different industrial sectors have to select the BAT that is appropriate for their conditions.

Finally, the change in average working hours in a very efficient way that could have a good impact on consumption and related environmental pressure (Bergh et al. 2011).

Even if the literature available is still low, some studies demonstrated that changing the times of going to work, shifts, brackets, rationalizing home-office travel times, and the rigidity of schedules can reduce traffic congestion and $\mathrm{CO}_{2}$ and fine dust emissions, PM10, and PM2.5 as well as employee stress with a positive return on the quality of work and the competitiveness of businesses (Ge et al. 2018). Furthermore, it is possible to improve air quality by promoting online work, avoiding not strictly necessary car moving. Another example is to support the vertical part-time (fewer days a week but more hours a day), halving the mowing toward the workplace.

\section{Agriculture and food sector}

The majority of fine particulate originates not only from combustion processes in traffic, power plants, industry, and household energy use but also from sources related to agriculture (Martins et al. 2015). One of the particulate precursors is ammonia $\left(\mathrm{NH}_{3}\right)$ after the reaction with the sulfuric and nitric acid (Erisman and Schaap 2004). It has been estimated that about $80 \%$ of $\mathrm{NH}_{3}$ entering in the atmosphere is produced by agricultural activities in Europe (Velthof et al. 2012). In agriculture, the main sources responsible for $\mathrm{NH}_{3}$ production are the excretion of urine by livestock and the manure storage (Velthof et al. 2012). There are many specific changes to mitigate $\mathrm{NH}_{3}$ emissions in agriculture (Giannadaki et al. 2018). These imply the improvement of the technology and the management of agricultural productions, but also include the reduction of food wastes combined with human diet optimization (Zhao et al. 2017). In fact, the $\mathrm{NH}_{3}$ emission levels depend on the animal typology, with higher amounts for beef and sheep, and a lower amount for pigs and poultry. Four strategies are identified in this study to reduce $\mathrm{NH}_{3}$ by focusing mainly on livestock:

1. Improvement in livestock farming efficiency: The livestock farming efficiency can be improved by supporting local farmers' markets and community gardens, in order to reduce the traveled distances of transported goods. Agriculture and land use increases the demand for deforestation, increasing the levels of atmospheric $\mathrm{CO}_{2}$ produced promoting climate change (Younger et al. 2008).

2. Manure management optimization: Besides $\mathrm{NH}_{3}$ emission, livestock manure contributes to other substances, mainly methane $\left(\mathrm{CH}_{4}\right)$ and nitrous oxide $\left(\mathrm{N}_{2} \mathrm{O}\right)$. These emissions derive from various phases in the use of manure ranging from the handling and storage to the application as a fertilizer to soils (Mohankumar et al. 2017). Some 
abatement options need to be developed like lowering the dietary crude protein content, external slurry storage via acidification, frequent removal of manure, and covers of straw or artificial films (Mohankumar et al. 2017) (Hou et al. 2015).

3. Reduction in the use of fossil fuels: Another revolution in agricultural sector concerns the reduction of dependence on non-renewable energy. Oil is also used to produce nitrogenous fertilizers (McMichael et al. 2007).

4. Reduction in the production and consumption of foods from animal sources: It is necessary to promote more healthy diets with low consumption of foods from animal sources (Friel et al. 2009).

\section{Shipping sector}

Nowadays, the shipping sector provides low-cost and reliable delivery services in the economic field (Arunachalam et al. 2015). Nevertheless, shipping-related activities have a considerable impact on air pollution, especially in coastal areas but also globally (Buccolieri et al. 2016). The primary air pollutants are PM, VOCs, $\mathrm{NO}_{x}, \mathrm{O}_{3}, \mathrm{SO}_{2}$, and $\mathrm{CO}$ (Bailey and Solomon 2004). As a consequence, a wide range of options toward "greener" seaports is needed (Bailey and Solomon 2004). Some of these measures are easy to adopt such as the regulation of fuel quality (by using low-sulfur alternative fuels), the speed reduction (Lack et al. 2011), and the use of alternative transportation equipment (Lai et al. 2011).

Furthermore, a variety of technical strategies for reducing ship emissions have to be adopted. $\mathrm{NO}_{x}$ and $\mathrm{SO}_{x}$ emission reduction strategies consist in lowering combustion temperature, switching to lower sulfur marine fuels and using seawater scrubbing (Han 2010). In addition, it is essential to operate in modifying the entry and the docking of ships in the harbor to reduce local emissions. A precautionary approach includes the dock electrification that means the shore-side power for docked vessels to avoid the motor power on during the stop (Dhupia et al. 2011).

\section{Recommendations to local/provincial/regional/national authorities}

Rapid industrialization, as well as urbanization in developing countries, has led to an increase in air pollution with adverse effects on human health. As a consequence, the development of city action plans that includes mitigation and adaptions strategies to emphasize pollutant emission reduction is an important step toward the better well-being of life. Therefore, the responsibility for urban areas such as governance bodies (lo$\mathrm{cal} / \mathrm{provincial} / \mathrm{regional} /$ national authorities) is involved in planning the correct strategies aimed at improving air quality. In this section, more comprehensive management measures focused on emphasizing pollutant and emission sources reductions at both local and regional levels are proposed to mitigate the air pollution issue. The options include the implementation of new regulations, urban planning reorganization, and promotion of hybrid vehicles with low emissions.

\section{New regulations}

Air quality management policies have to fix new air quality standards that maximize overall population benefits, reduce illness related to air pollution and gas emissions from industrial, urban, or domestic activities (Fann et al. 2011). It is essential to identify effective structural and exceptional measures throughout the national territory.

\section{Advisory and prevention}

Frequently, acting with mitigation strategies after critical levels of pollution does not solve the pollution emergency. For this reason, it is necessary to move toward a "preventive approach to the emergency" by promoting effective measures before reaching critical levels of pollution (Bandyopadhyay et al. 2014). In this context, the authorities should support new technologies for air pollution monitoring (Mishra et al. 2015). Air pollution monitoring networks offer the possibility to measure the spatiotemporal distribution of air pollution in the urban environment for the health and safety of citizens (Singla et al. 2018) (Sofia et al. 2018a). For example, sensor networks offer the potential to focus on air pollution monitoring reflecting high spatial and temporal variability in pollutant levels (Knox et al. 2013) (Sofia et al. 2018b). In this way, if a particular pollutant exceeds the target limit, efficient strategies should be adopted to mitigate the air pollution issue and find the pollution sources. Furthermore, air quality prediction models are another way to make a rational decision by political leaders (Vicente et al. 2018). The combination of air quality monitoring and modeling is a valid approach for regulatory purposes (Vlachokostas et al. 2011).

\section{Urban planning}

Rapid urbanization has involved significant challenges in urban areas with dramatic consequences in air quality. The primary source of atmospheric pollution is vehicular traffic (Pospisil and Jicha 2017). The emissions from vehicles are different throughout the day with a maximum concentration during the more congested hours (Kumar et al. 2016). Therefore, policymakers have to support the implementation of strategies and actions aimed at reducing air pollution in urban areas while promoting economic growth and higher quality of life (Vranckx et al. 2015). In this context, the 
concept of "smart city" has emerged as a way to respond to the inhabitants' needs more efficiently and sustainably. In urban planning, smart mobility represents a crucial factor. Since a major part of pollutant emissions in cities are due to traffic, an appropriate transport design in the urban area is needed (Cariolet et al. 2018). Political leaders have to promote changes in travel behaviors by supporting public transport (Sellitto et al. 2015) and the sharing of mobility. The strong inclination toward traffic congestion reduction promoted by policymakers is not always conformed to health promotion. Appropriate safety interventions must be proposed to have health benefits, especially for cyclists and pedestrians (Rojas-Rueda et al. 2016).

Regarding public bicycle sharing, it is now spreading in different countries in Europe, Asia, and America as a healthier transport system in the urban context (Rojas-Rueda et al. 2011). In addition, the reduction in private car use can be reached only ensuring public transport availability, cycling infrastructure, and green spaces (Panter et al. 2016). Currently, many cities in the world are moving toward mobility solutions implementing car-free days, strengthening the infrastructures and public transport (Nieuwenhuijsen and Khreis 2016). The objective is to reduce the traffic-related air pollution and provide strong opportunities to increase free spaces that can be used to improve the urban green with parks and open areas or attractive places (public squares, shops) for citizens and tourists (Nieuwenhuijsen and Khreis 2016). Furthermore, the reduction in vehicular traffic will certainly lead other human health benefits like the reduction of road accidents (Nieuwenhuijsen and Khreis 2016). All these mitigation measures have to be promoted in the long-term to obtain significant changes in emission reductions and human health benefits. In fact, in evaluating the effects of commonly adopted mitigation strategies such as car free-days in a large city of Po Valley (Northern Italy), Masiol and their colleagues (Masiol et al. 2014) did not find significant changes probably due to the very short time of mitigation procedure (Masiol et al. 2014).

In addition, the reduction in private cars use promotes the increase in public space for vegetation and retail goals. Roadside vegetation barriers can be a potential mitigation strategy for near-road air pollution (Isakov et al. 2017). In their work, Tong et al. (2016) demonstrated that a wide vegetation barrier combined with a solid barrier reduces pollutant concentrations significantly (Tong et al. 2016). Urban vegetation impacts our ecosystem positively by filtrating airborne particulate matter, providing a scenic public landscape and reducing flooding consequences (Al-thani et al. 2018).

\section{Promotion of hybrid vehicles}

It is well known that vehicle emissions (NOx, $\mathrm{HC}, \mathrm{O}_{3}, \mathrm{VOC}$, $\mathrm{CO}$, and PM) contribute to air pollution (Wu et al. 2017). In this scenario, besides the implementation of increasingly stringent standards for vehicle emissions, the most effective policy is the promotion of the zero-emission vehicle (Perez et al. 2015). In particular, by using alternative fuels, respect to the traditional fossil ones, like electricity, bio-fuels, liquefied petroleum gas (LPG), natural gas (CHG, LNG), and, methane, this kind of cars can produce lower concentrations of pollutants (Qiu et al. 2016).

Fig. 2 The mitigation strategies or strategic measures proposed that can be adopted by different stakeholders to obtain public health co-benefits with air pollution reduction

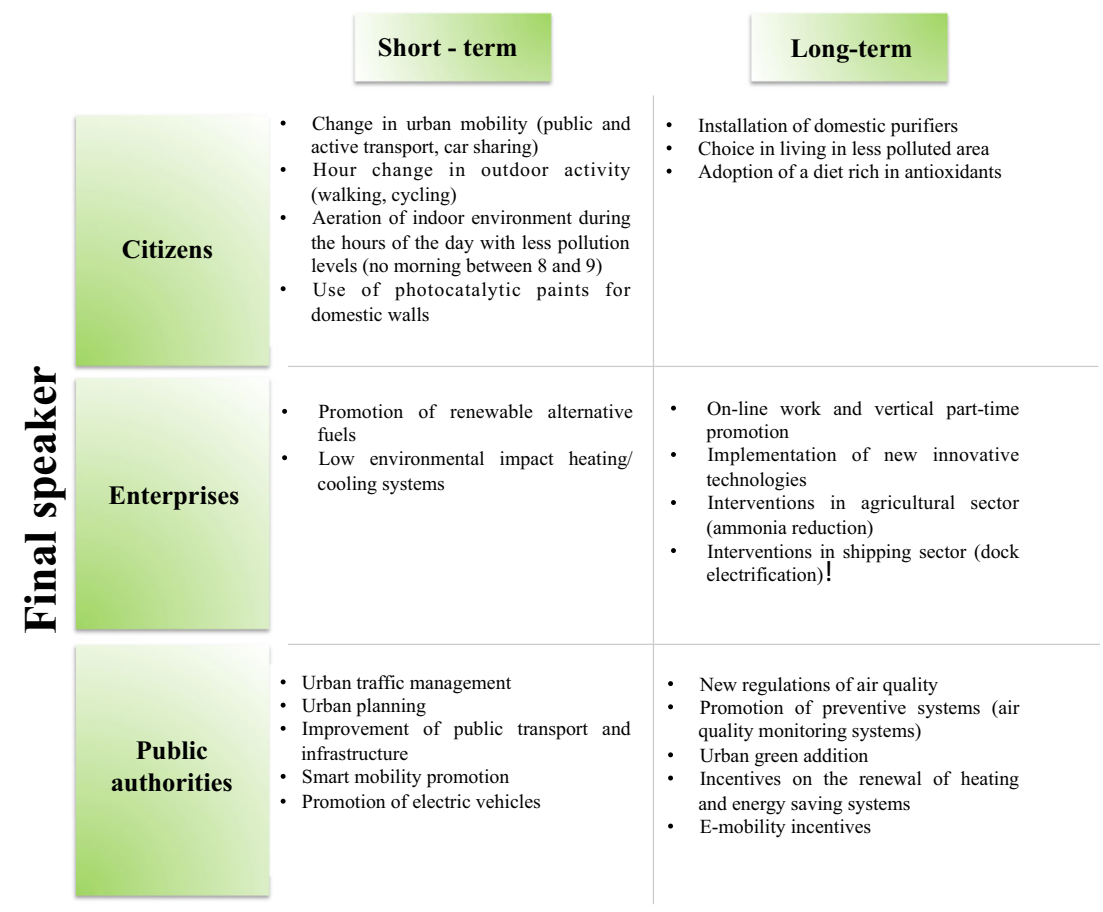


With the rapid industrialization, the hybrid electric vehicle (HEV) technology is a valid alternative to the fuel prices rising and to satisfy the more effective environmental policies (Xia et al. 2015) (Sabri et al. 2016). The combination to active travel with zero-emission vehicles can reduce the cases of ischemic heart disease (Woodcock et al. 2009). The government has to make a series of laws aimed at encouraging electric mobility such as tax incentives and lower prices for usage or parking (Leurent and Windisch 2011).

\section{Conclusions}

This study summarizes the mitigation strategies that can be adopted by different stakeholders (citizens, companies, and committees) to obtain public health co-benefits with air pollution reduction. In particular, specific guidelines were provided in various sectors: transportation, industry, household, energy generation, agriculture, and shipping sector. These guidelines can be considered a basis for governments for the implementation of a strategic plan focused on the reduction of multipollutant emission, as well as of the overall air pollutionrelated risk. Individuals can also adopt environmental friendlier behaviors that together with mitigation policies, can obtain health and environment co-benefits. The strategic measures proposed, differing for the stakeholder (citizens, enterprises, and public authorities) on the application kind (direct/indirect measure), for the emission sources (transport, household energy, industry and energy generation sector, food, and agriculture) and for the area of implementation (urban and extraurban context) that can be reassumed by Fig. 2 .

Funding information The authors would like to thank the Regione Campania with grant no. B52C18000150007 for their financial support.

\section{References}

Al-thani H, Koç M, Isaifan RJ (2018) A review on the direct effect of particulate atmospheric pollution on materials and its mitigation for sustainable cities and societies. Environ Sci Pollut Res 25(28): 27839-27857

Anderson JO, Thundiyil JG, Stolbach A (2012) Clearing the air: a review of the effects of particulate matter air pollution on human health. $\mathrm{J}$ Med Toxicol 8(2):166-175

Arunachalam S, Brantley H, Barzyk TM, Hagler G, Isakov V, Kimbrough E, Naess B, Rice N, Snyder MG, Talgo K, Venkatram A (2015) Assessment of port-related air quality impacts: geographic analysis of population. Int J Environ Pollut 58(4):231-250

Babar ZB, Shareefdeen Z (2014) Management and control of air emissions from electronic industries. Clean Techn Environ Policy 16(1): 69-77

Bailey D, Solomon G (2004) Pollution prevention at ports: clearing the air. Environ Impact Assess Rev 24(7):749-774

Bandyopadhyay A, Bandyopadhyay S, Biswas MN (2014) Fabrication and operation of an online photoelectric particulate matter monitoring device. Clean Techn Environ Policy 17(1):265-271
Barca D, Comite V, Belfiore CM, Bonazza A, La Russa MF, Ruffolo SA, Crisci GM, Pezzino A, Sabbioni C (2014) Impact of air pollution in deterioration of carbonate building materials in Italian urban environments. Appl Geochem 48:122-131

Bergh J, Van Den CJM, Allen W (2011) Environment versus growth - a criticism of 'degrowth' and a Plea for 'a-growth'. Ecol Econ 70(5): 881-890

Biesbroek S, Bueno-De-Mesquita HB, Peeters PHM, Verschuren WM, Van Der Schouw YT, Kramer GFH, Tyszler M, Temme EHM (2014) Reducing our environmental footprint and improving our health: greenhouse gas emission and land use of usual diet and mortality in EPIC-NL: a prospective cohort study. Environ Health 13(1):1-9

Block ML, Calderon-Garciduenas L (2009) Air pollution: mechanism of neuroinflammation and CNS disease. Trends Neurosci 32(9):506516

Brancato V, Gioiella F, Imparato G, Guarnieri D, Urciuolo F, Netti PA (2018) 3D breast Cancer microtissue reveals the role of tumor microenvironment on the transport and efficacy of free-doxorubicin in vitro. Acta Biomater 75:200-212

Brugha R, Grigg J (2014) Urban air pollution and respiratory infections. Paediatr Respir Rev 15(2):194-199

Buccolieri R, Cesari R, Dinoi A, Maurizi A, Tampieri F, Di Sabatino S (2016) Impact of ship emissions on local air quality in a Mediterranean City's harbour after the European sulphur directive. Int J Environ Pollut 59(1):30-42

Buonanno G, Marini S, Morawska L, Fuoco FC (2012) Individual dose and exposure of Italian children to ultrafine particles. Sci Total Environ 438:271-277

Buonanno G, Stabile L, Morawska L (2014) Personal exposure to ultrafine particles: the influence of time-activity patterns. Sci Total Environ 468-469:903-907

Buonanno G, Stabile L, Morawska L, Giovinco G, Querol X (2017) Do air quality targets really represent safe limits for lung cancer risk? Sci Total Environ 580:74-82

Cariolet JM, Colombert M, Vuillet M, Diab Y (2018) Assessing the resilience of urban areas to traffic-related air pollution: application in greater Paris. Sci Total Environ 615(615):588-596

Chae Y, Park J (2011) Quantifying costs and benefits of integrated environmental strategies of air quality management and greenhouse gas reduction in the Seoul metropolitan area. Energy Policy 39(9):5296 5308

Chao K (2008) A new look at the cross-impact matrix and its application in futures studies. J Futures Stud 12(4):45-52

Conti ME, Ciasullo R, Tudino MB, Matta EJ (2015) "The industrial emissions trend and the problem of the implementation of the industrial emissions directive (IED)" Air Quality. Atmosph Health 8(2): $151-161$

Contreras-Zarazúa G, Villicaña-García E, Cansino-Loeza B, VázquezCastillo JA, Ponce-Ortega JM, Segovia-Hernández JG (2018) Environmental impact and occupational Hazard evaluation on intensified processes to produce diphenyl carbonate. Comput Chem Eng: $1-12$

Crouse DL, Goldberg MS, Ross NA, Chen H, Labreche F (2010) Postmenopausal breast Cancer is associated with exposure to traffic-related air pollution in Montreal, Canada: a case-control study. Environ Health Perspect 118(11):1578-1583

Dales RE, Cakmak S, Vidal CB (2009) Air pollution and hospitalization for headache in Chile. Am J Epidemiol 170(8):1057-1066

Datta A, Sharma VP, Gaine T, Sehgal M (2017) Mitigation of domestic indoor air pollution in a pristine rural area of India. Manag Environ Qual 28:231-247

Debnath R, Bardhan R, Banerjee R (2017) Taming the killer in the kitchen: mitigating household air pollution from solid-fuel cookstoves through building design. Clean Techn Environ Policy 19(3):705719 
Dhupia J, Adnanes AK, Lee KM Kennedy L (2011) Electrification of port and port operations. Proceedings of MTEC2011, pp. 1-6

Erisman JW, Schaap M (2004) The need for ammonia abatement with respect to secondary PM reductions in Europe. Environ Pollut 129(1):159-163

Fajersztajn L, Veras M, Barrozo LV, Saldiva P (2013) Air pollution: a potentially modifiable risk factor for lung cancer. Nat Rev Cancer 13(9):674-678

Fann N, Roman HA, Fulcher CM, Gentile MA, Hubbell BJ, Wesson K, Levy JI (2011) Maximizing health benefits and minimizing inequality: incorporating local-scale data in the design and evaluation of air quality policies. Risk Anal 31(6):908-922

Friel S, Dangour AD, Garnett T, Lock K, Chalabi Z, Roberts I, Butler A, Butler CD, Waage J, McMichael AJ, Haines A (2009) Public health benefits of strategies to reduce greenhouse-gas emissions: food and agriculture. Lancet 374(9706):2016-2025

$\mathrm{Fu} \mathrm{H}$, Chen J (2017) Formation, Features and controlling strategies of severe haze-fog pollutions in China. Sci Total Environ 578:121-138

Gao J, Hou H, Zhai Y, Woodward A, Vardoulakis S, Kovats S, Wilkinson P, Li L, Song X, Xu L, Meng B, Liu X, Wang J, Zhao J, Liu Q (2018) Greenhouse gas emissions reduction in different economic sectors: mitigation measures, health co-benefits, knowledge gaps, and policy implications. Environ Pollut 240(1):683-698

Ge J, Polhill JG, Craig TP (2018) Too much of a good thing? Using a spatial agent-based model to evaluate "unconventional" workplace sharing programmes. J Transp Geogr 69:83-97

Giannadaki D, Giannakis E, Pozzer A, Lelieveld J (2018) Estimating health and economic benefits of reductions in air pollution from agriculture. Sci Total Environ 622-623:1304-1316

Giuliano A, Gioiella F, Sofia D, Lotrecchiano N (2018a) A novel methodology and technology to promote the social acceptance of biomass Power plants avoiding Nimby syndrome. Chem Eng Trans 67: 307-312

Giuliano A, Poletto M, Barletta D (2018b) Pure hydrogen co-production by membrane technology in an IGCC power plant with carbon capture. Int J Hydrog Energy 43(41):19279-19292

Goss CH, Newsom SA, Schildcrout JS, Sheppard L, Kaufman JD (2004) Effect of ambient air pollution on pulmonary exacerbations and lung function in cystic fibrosis. Am J Respir Crit Care Med 169(7):816821

Guan WJ, Zheng XY, Chung KF, Zhong NS (2016) Impact of air pollution on the burden of chronic respiratory diseases in China: time for urgent action. Lancet 388(10054):1939-1951

Guersola M, Steiner MTA, Scarpin CT (2017) A methodology for minimizing LPG transportation impact. Manag Environ Qual 28:807820

Han CH (2010) Strategies to reduce air pollution in shipping industry. Asian J Ship Logistic 26(1):7-30

Harlan SL, Ruddell DM (2011) Climate change and health in cities: impacts of heat and air pollution and potential co-benefits from mitigation and adaptation. Current Option in Environmental Sustainability 3(3):126-134

Hou Y, Velthof GL, Oenema O (2015) Mitigation of Ammonia, nitrous oxide and methane emissions from manure management chains: a meta-analysis and integrated assessment. Glob Chang Biol 21(3): $1293-1312$

Ibáñez-Forés V, Bovea MD, Azapagic A (2013) Assessing the sustainability of best available techniques (BAT): methodology and application in the ceramic tiles industry. J Clean Prod 51:162-176

Invernizzi S, Montagnoli F, Carpinteri A (2019) Fatigue assessment of the collapsed $\mathrm{XX}^{\text {th }}$ century cable-stayed Polcevera bridge in Genoa. Proced Struct Integ 18:237-244

Isakov V, Venkatram A, Baldauf R, Deshmukh P, Zhang M (2017) Evaluation and development of tools to quantify the impacts of roadside vegetation barriers on near-road air quality. Int J Environ Pollut 62(2):127-135
Karka P, Papadokonstantakis S, Kokossis A (2017) Cradle-to-gate assessment of environmental impacts for a broad set of biomass-to-product process chains. Int J Life Cycle Assess 22(9):1418-1440

Kelly FJ, Dunster C, Mudway I (2003) Air pollution and the elderly: oxidant/antioxidant issues worth consideration. Eur Respir J 40: $70 \mathrm{~s}-75 \mathrm{~s}$

Knox A, Mykhaylova N, Evans GJ, Lee CJ, Karney B, Brook JR (2013) The expanding scope of air pollution monitoring can facilitate sustainable development. Sci Total Environ 448:189-196

Kumar A, Patil RS, Dikshit AK, Kumar R (2016) Comparison of predicted vehicular pollution concentration with air quality standards for different time periods. Clean Techn Environ Policy 18(7):22932303

Kurmi OP, Semple S, Simkhada P, Smith WCS, Ayres JG (2010) COPD and chronic bronchitis risk of indoor air pollution from solid fuel: a systematic review and meta-analysis. Thorax 65(3):221-228

Kwong QJ, Abdullah J, Chuan Tan S, Thio THG, Yeaw WS (2019) A field study of indoor air quality and occupant perception in experimental laboratories and workshops. Manag Environ Qual 30:467482

Lack DA, Cappa CD, Langridge J, Bahreini R, Buffaloe G, Brock C, Cerully K, Coffman D, Hayden K, Holloway J, Lerner B, Massoli P, Li SM, McLaren R, Middlebrook AM, Moore R, Nenes A, Nuaaman I, Onasch TB, Peischl J, Perring A, Quinn PK, Ryerson T, Schwartz JP, Spackman R, Wofsy SC, Worsnop D, Xiang B, Williams E (2011) Impact of fuel quality regulation and speed reductions on shipping emissions: implications for climate and air quality. Environ Sci Technol 45(20):9052-9060

Lai KH, Lun VYH, Wong CWY, Cheng TCE (2011) Green shipping practices in the shipping industry: conceptualization, adoption, and implications. Resour Conserv Recycl 55(6):631-638

Lee BK, Cho SW (2003) Strategies for emission reduction of air pollutants produced from a chemical plant. Environ Manag 31(1):42-49

Leurent F, Windisch E (2011) Triggering the development of electric mobility: a review of public policies. Eur Transp Res Rev 3(4): $221-235$

Levy RJ (2015) Carbon monoxide pollution and neurodevelopment: A public health concern. Neurotoxicol Teratol 49:31-40

Lindsay G, Macmillan A, Woodward A (2011) Moving urban trips from cars to bicycles: impact on health and emissions. Aust N Z J Public Health 35(1):54-60

Liu X, Wen Z (2012) Best available techniques and pollution control: a case study on China's thermal power industry. J Clean Prod 23:113121

Maheswaran R (2016) Air pollution and stroke - an overview of the evidence base. Spatial Spatio-temp Epidemiol 18:74-81

Mainka A, Zajusz-Zubek E, Kaczmarek K (2015) PM10 composition in urban and rural nursery schools in upper Silesia, Poland: trace elements analysis. Int J Environ Res Public Health 12(7):7990-8008

Maizlish N, Woodcock J, Co S, Ostro B, Fanai A, Fairley D (2013) Health cobenefits and transportation-related reductions in greenhouse gas emissions in the San Francisco Bay Area. Am J Public Health 103(4):703-709

Marchetti LE, Bengalli R, Avino P, Stabile L, Buonanno G, Colombo A, Camatini M, Mantecca P (2019) In vitro lung toxicity of indoor PM10 from a stove fueled with different biomasses. Sci Total Environ 649:1422-1433

Martins H, Monteiro A, Ferreira J, Gama C, Ribeiro I, Borrego C, Miranda AI (2015) The role of ammonia on particulate matter pollution over Portugal. Int J Environ Pollut 57(3/4):215-226

Masiol M, Agostinelli C, Formenton G, Tarabotti E, Pavoni B (2014) Thirteen years of air pollution hourly monitoring in a large city: potential sources, trends, cycles and effects of car-free days. Sci Total Environ 494(495):84-96 
McMichael AJ, Powles JW, Butler CD, Uauy R (2007) Food, livestock production, energy, climate change, and health. Lancet 370(9594): $1253-1263$

Metallo MC, Poli AA, Diana M, Persia F, Cirillo MC (1995) Air pollution loads on historical monuments: an air quality model application to the marble arch of Titus in Rome. Sci Total Environ 171:63-172

Mishra RK, Joshi T, Goel NI, Gupta H, Kumar A (2015) Monitoring and analysis of PM 10 concentration at Delhi Metro construction sites. Int J Environ Pollut 57(1/2):27-37

Mohankumar S, Purath E, Winiwarter W, Amon B (2017) Greenhouse gas and ammonia emissions from different stages of liquid manure management chains: abatement options and emission interactions. J Environ Qual 47(1):30-41

Mueller N, Rojas-Rueda D, Cole-Hunter T, de Nazelle A, Dons E, Gerike R, Götschi T, Int Panis L, Kahlmeier S, Nieuwenhuijsen M (2015) Health impact assessment of active transportation: a systematic review. Prev Med 76:103-114

Nieuwenhuijsen MJ, Khreis H (2016) Car free cities: pathway to healthy urban living. Environ Int 94:251-262

Panter J, Heinen E, Mackett R, Ogilvie D (2016) Impact of new transport infrastructure on walking, cycling, and physical activity. Am J Prev Med 50(2):45-53

Pask F, Lake P, Yang A, Tokos H, Sadhunkhan J (2017) Industrial oven improvement for energy reduction and enhanced process performance. Clean Techn Environ Policy 19(1):215-224

Perez L, Trüeb S, Cowie H, Keuken MP, Mudu P, Ragettli MS, Sarigiannis DA, Tobollik M, Tuomisto J, Vienneau D, Sabel C, Künzli N (2015) Transport-related measures to mitigate climate change in Basel, Switzerland: a health-effectiveness comparison study. Environ Int 85:111-119

Porritt S, Shao L, Cropper P, Goodier C (2011) Adapting dwellings for heat waves. Sustain Cities Soc 1(2):81-90

Porritt SM, Cropper PC, Shao L, Goodier CI (2012) Ranking of interventions to reduce dwelling overheating during heat waves. Energy Build 55:16-27

Pospisil J, Jicha M (2017) Influence of vehicle-induced turbulence on pollutant dispersion in street canyon and adjacent urban area. Int $\mathrm{J}$ Environ Pollut 62:2-4

Power MC, Kioumourtzoglou M-A, Hart JE, Okereke OI, Laden F, Weisskopf MG (2015) The relation between past exposure to fine particulate air pollution and prevalent anxiety: observational cohort study. BMJ 350:1-9

Power MC, Adar SD, Yanosky JD, Weuve J (2016) Exposure to air pollution as a potential contributor to cognitive function, cognitive decline, brain imaging, and dementia: A systematic review of epidemiologic research. NeuroToxicology 56:235-253

Qiu Z, Li X, Hao Y, Deng S (2016) Potential of diesel emissions reduction strategies in Xi'an, China. Clean Techn Environ Policy 18(8):27172724

Raaschou-Nielsen O, Zorana AJ, Beelen R, Samoli E, Stafoggia M, Weinmayr G, Hoffmann B, Fischer P, Nieuwenhuijsen MJ, Brunekreef B, Xun WW, Katsouyanni K, Dimakopoulou K, Sommar J, Forsberg B, Modig L, Oudin A, Oftedal B, Schwarze PE, Nafstad P, De Faire U, Pedersen NL, Östenson CG, Fratiglioni L, Penell J, Korek M et al (2013) Air pollution and lung cancer incidence in 17 European cohorts: prospective analyses from the European study of cohorts for air pollution effects (ESCAPE). Lancet Oncol 14(9):813-822

Rabl A, de Nazelle A (2012) Benefits of shift from car to active transport. Transp Policy 19(1):121-131

Ren WX, Geng Y, Xue B, Fujita T, Ma Z, Jiang P (2012) Pursuing cobenefits in China's old industrial base: a case of Shenyang. Urban Clim 1(72):55-64

Ribeiro I, Monteiro A, Martins H, Freitas S, Borrego C, Lopes M (2015) How does the use of biodiesel affect urban air quality? Int J Environ Pollut 58:79-88
Rodriguez de San Miguel JA (2019) Management of air pollution in Mexico. Manag Environ Qual 30:578-592

Rojas-Rueda D, de Nazelle A, Tainio M, Nieuwenhuijsen MJ (2011) The health risks and benefits of cycling in urban environments compared with car use: health impact assessment study. Bmj 343:1-8

Rojas-Rueda D, De Nazelle A, Andersen ZJ, Braun-Fahrländer C, Bruha J, Bruhova-Foltynova H, Desqueyroux H, Praznoczy C, Ragettli MS, Tainio M, Nieuwenhuijsen MJ (2016) Health impacts of active transportation in Europe. PLoS One 11(3):1-14

Romieu I, Sienra-Monge JJ, Ramírez-Aguilar M, Téllez-Rojo MM, Moreno-Macías H, Reyes-Ruiz NI, Del Río-Navarro BE, RuizNavarro MX, Hatch G, Slade R, Hernández-Avila M (2002) Antioxidant supplementation and lung functions among children with asthma exposed to high levels of air pollutants. Am J Respir Crit Care Med 166(5):703-709

Ruparathna R, Hewage K, Sadiq R (2017) Rethinking investment planning and optimizing net zero emission buildings. Clean Techn Environ Policy 19(6):1711-1724

Sabri MF, Danapalasingam KA, Rahmat MF (2016) A review on hybrid electric vehicles architecture and energy management strategies. Renew Sust Energ Rev 53:1433-1442

Salehi KH, Sofia D, Barletta D, Poletto M (2015) Dust generation in vibrated cohesive powders. Chem Eng Trans 43(1):769-774

Sarigiannis DA, Kontoroupis P, Nikolaki S, Gotti A, Chapizanis D, Karakitsios S (2017) Benefits on public health from transportrelated greenhouse gas mitigation policies in southeastern European cities. Sci Total Environ 579:1427-1438

Scheepers CE, Wendel-Vos GCW, den Broeder JM, van Kempen EEMM, van Wesemael PJV, Schuit AJ (2014) Shifting from car to active transport: a systematic review of the effectiveness of interventions. Transp Res A Policy Pract 70:264-280

Sellitto MA, Borchardt M, Pereira GM, Bubicz ME (2015) Tool for environmental performance assessment of city bus transit operations: case studies. Clean Techn Environ Policy 17(4):1053-1064

Settimo G (2015) Existing guidelines for indoor air quality: the case study of hospital environments. Indoor Air Qual Healthc Facilities:13-27

Shrestha RM, Shakya SR (2012) Benefits of low carbon development in a developing country: case of Nepal. Energy Econ 34(Suppl. 3): S503-S512

Singla S, Bansal D, Misra A (2018) Towards an integrated framework for air quality monitoring and exposure estimation - a review. Environ Monit Assess 190(562)

Sofia D, Joshi YA, Poletto M (2013) Kinetics of bioethanol production from lactose converted by Kluyveromyces Marxianus. Chem Eng Trans 32:1135-1140

Sofia D, Giuliano A, Gioiella F (2018a) Air quality monitoring network for tracking pollutants: the CASE study of Salerno city center. Chem Eng Trans 68:67-72

Sofia D, Giuliano A, Gioiella F, Barletta D, Poletto M (2018b) Modeling of an air quality monitoring network with high space-time resolution. Comput Aided Chem Eng 48:193-198

Sripada PP, Xu T, Kibria MA, Bhattacharya S (2017) Comparison of entrained flow gasification behaviour of Victorian Brown coal and biomass. Fuel 203:942-953

Stabile L, Jayaratne ER, Buonanno G, Morawska L (2014) Charged particles and cluster ions produced during cooking activities. Sci Total Environ 497(498):516-526

Stabile L, Buonanno G, Avino P, Frattolillo A, Guerriero E (2018) Indoor exposure to particles emitted by biomass-burning heating systems and evaluation of dose and lung cancer risk received by population. Environ Pollut 235:65-73

Tong Z, Baldauf RW, Isakov V, Deshmukh P, Max Zhang K (2016) Roadside vegetation barrier designs to mitigate near-road air pollution impacts. Sci Total Environ 541:920-927

Velthof GL, van Bruggen C, Groenestein CM, de Haan BJ, Hoogeveen MW, Huijsmans JFM (2012) A model for inventory of ammonia 
emissions from agriculture in the Netherlands. Atmos Environ 46: $248-255$

Venkataraman C, Sagar AD, Habib G, Lam N, Smith KR (2010) The Indian National Initiative for advanced biomass cookstoves: the benefits of clean combustion. Energy Sustain Dev 14(2):63-72

Vicente B, Rafael S, Rodrigues V, Relvas H, Vilaça M, Teixeira J, Bandeira J, Coelho M, Borrego C (2018) Influence of different complexity levels of road traffic models on air quality modelling at street scale. Air Qual Atmos and Health 11:1217-1232

Vlachokostas C, Achillas C, Moussiopoulos N, Banias G (2011) Multicriteria methodological approach to manage urban air pollution. Atmos Environ 45(25):4160-4169

Vranckx S, Lefebvre W, van Poppel M, Beckx C, Theunis J (2015) Air quality impact of intelligent transportation system actions used in a decision support system for adaptive traffic management. Int $\mathrm{J}$ Environ Pollut 57(3/4):133-145

Werner M, Kryza M, Dore AJ (2015) Mean annual population exposure to atmospheric particulate matter in Poland. Int J Environ Pollut 58(1-2):89-99

Woodcock J, Edwards P, Tonne C, Armstrong BG, Ashiru O, Banister D, Beevers S, Chalabi Z, Chowdhury Z, Cohen A, Franco OH, Haines A, Hickman R, Lindsay G, Mittal I, Mohan D, Tiwari G, Woodward A, Roberts I (2009) Public health benefits of strategies to reduce greenhouse-gas emissions: urban land transport. Lancet 374(9705):1930-1943
Wu Y, Zhang S, Hao J, Liu H, Wu X, Hu J, Walsh MP, Wallington TJ, Zhang KM, Stevanovic S (2017) On-road vehicle emissions and their control in China: a review and outlook. Sci Total Environ 574:332-349

Xia T, Nitschke M, Zhang Y, Shah P, Crabb S, Hansen A (2015) Trafficrelated air pollution and health co-benefits of alternative transport in Adelaide, South Australia. Environ Int 74:281-290

Yang C, Zhao W, Deng K, Zhou V, Zhou X (2017) The association between air pollutants and autism spectrum disorders. Environ Sci Pollut Res 24:15949-15958

Younger M, Morrow-Almeida HR, Vindigni SM, Dannenberg AL (2008) The built environment, climate change, and health. Opportunities for co-benefits. Am J Prev Med 35(5):517-526

Zanobetti A, Schwartz J (2005) The effect of particulate air pollution on emergency admissions for myocardial infarction: a multicity Casecrossover analysis. Environ Health Perspect 113(8):978-982

Zhao ZQ, Bai ZH, Winiwarter W, Kiesewetter G, Heyes C, Ma L (2017) Mitigating ammonia emission from agriculture reduces PM2.5 pollution in the Hai River basin in China. Sci Total Environ 609:11521160

Publisher's note Springer Nature remains neutral with regard to jurisdictional claims in published maps and institutional affiliations. 